\title{
ДО ЮВІЛЕЮ ВИДАТНОГО ВЧЕНОГО Б. П. ГРОМОВИКА
}

4 серпня 2017 року виповнилося 60 років завідувачу кафедри організації та економіки фрармації Львівського національного медичного університету імені Данила Галицького Богдану Петровичу Громовику, доктору фрармацевтичних наук, просресору, провізору, досвідченому організатору та педагогу.

Богдан Петрович пройшов шлях від студента, практикуючого провізора, асистента, доцента, професора до завідувача кафедри і декана фракультету.

Народився Б. П. Громовик у м. Зборів на Тернопільщині. Після закінчення Зборівської середньої школи у 1975 році вступив на фрармацевтичний фракультет Львівського державного медичного інституту, який закінчив 3 відзнакою у 1980 році.

Після закінчення інституту за скеруванням Міністерства охорони здоров'я працював на провізорських посадах в Чернігівському та Тернопільському обласних аптечних управліннях (1980-1983 рр.).

У серпні 1983 року Б. П. Громовик обійняв посаду асистента кафедри організації та економіки фрармації Львівського державного медичного інституту. У 1988 році успішно захистив кандидатську дисертацію на тему «Оптимізація ефективності та якості роботи контрольно-аналітичної служби» і отримав науковий ступінь кандидата фрармацевтичних наук. У березні 1995 року Б.П. Громовика переведено на посаду, а в квітні 1996 року присвоєно звання доцента кафедри організації та економіки фармації.

32004 до 2009 року Б. П. Громовик працював в Одеському державному медичному університеті спершу на посаді доцента (2004-2006 рр.), а потім після блискучого захисту у 2006 році докторської дисертації на тему «Теоретико-методологічні та прикладні засади логістичного управління фрармацевтичними підприємствами» - професора кафедри організації та економіки фрармації. В подальшому Бог- дан Петрович продовжує займатись науковими дослідженнями в напрямку розвитку теорії та практики фрармацевтичного управління.

У 2009 році Богдан Петрович повернувся у Львівський національний медичний університет імені Данила Галицького на посаду профресора кафедри організації і економіки фрармації та технології ліків фракультету післядипломної освіти і вже у 2012 р. виконує обов'язки завідувача цієї кафредри. 32012 до 2015 року Б. П. Громовик - завідувач, а у 2015-2016 рр. профресор профрільної кафедри фрармацевтичного фракультету кафредри організації та економіки орармації. Одночасно у 20142015 роках Богдана Петровича призначили деканом фрармацевтичного фракультету. У 2016 році Б. П. Громовик повернувся на посаду завідувача кафедри організації та економіки фрармації.

На посаді завідувача кафедри і декана фракультету профресор Б. П. Громовик доклав багато зусиль та енергії для організації та вдосконалення навчальнометодичної роботи кафедри та фракультету. Богдан Петрович вдало поєднує наукову, викладацьку та адміністративну роботу.

Б. П.Громовик має великий науковий доробок. Він $€$ автором понад 550 наукових і навчальних методичних праць, серед них 15 монографій, 6 підручників, 13 навчальних посібників, один довідник.

Невтомний в наукових пошуках наставник, він підготував трьох докторів і трьох кандидатів фрармацевтичних наук та був визнаний як найкращий науковець за підсумками Національного рейтингу учасників фрармацевтичного ринку України «Фармація - 2006».

Колектив кафедри організації та економіки фрармації Львівського національного медичного університету щиро вітає ювіляра і бажає йому міцного здоров'я, родинного щастя, добробуту, благополуччя, життєвого оптимізму та творчої наснаги!

ISSN 2312-0967. Фармацевтичний часопис. 2017. № 3 